\title{
'The Most Beautiful Jewesses in the Land': Imperial Travel in the Early Christian Holy Land
}

\author{
Andrew S. Jacobs
}

\begin{abstract}
This essay examines the ways in which Jews were encoded into the holy land travel literature of the Christian Roman Empire (fourth through sixth centuries) as a means of naturalising and authenticating new modes of Christian, imperial power. Postcolonial criticism is used to analyse pilgrimage texts of the holy land (the Bordeaux pilgrim, Egeria, the Piacenza pilgrim) in order to explore various modes of constructing imperial Christian identity through use of the 'figural Jew' of ancient Palestine.

(C) 2002 Elsevier Science Ltd. All rights reserved.
\end{abstract}

\section{Mapping Christian Empire}

In the intriguing and idiosyncratic Christian Topography, composed in the sixth century by the otherwise unknown merchant and traveler called Cosmas Indicopleustès ('India-Sailer'), the physical world is at once entirely Christian and entirely imperial (Wolska 1962, pp. 1-12, 28-9). From his own travels and intense piety Cosmas has inferred that the cosmic space of the universe is laid out in the shape of the tabernacle as described in the Christian Old Testament (Top. chr., 2.35-6 [SC 141, p. 343]), ${ }^{1}$ and the political space of the known world is understood through the rise and success of the Christian Roman Empire:

The Roman Empire shares in the honors of the empire of the master, Christ, surpassing all others as much as is possible in this life, remaining invincible until the consummation of time. . . As for the Roman Empire, insofar as it grew up together with Christ, it will not be destroyed in this time (Top. chr., 2.75 [SC 141, p. 391]).

The notion of Christian triumphalism was hardly new in the sixth century: since the Emperor Constantine had first publicly endorsed the hitherto illicit religious movement in the fourth century, Christian writers had been quick to align Roman power and Christian success. By the sixth century, however, the universal notion of Christian Empire has acquired a more explicit material dimension, as evident in one of Cosmas' arguments for the power and extent of the Christian Roman Empire:

Here is another sign of the sovereignty of the Romans with which God has graced them, for I say indeed that it is in their coin that all the nations trade, and in every place, from one tip of the land to the other, it is accepted, admired by every person and every kingdom, of which no other kingdom can boast (Top. chr., 2.77 [SC 141, p. 393]; see Cansdale 1995).

Roman money has come to signal Roman power; since Roman dominion also reflects Christian sovereignty, the universal exchange of Roman coin is a gleaming symbol of the universal Christian message.

The process by which Christian triumph could come to be expressed in terms of material expansion necessitated nothing less than the fleshly incarnation of discourses of Christian knowledge: abstract notions of dominion and empire, of piety and reverence, were manifested through discursive representations of material control (see Elsner \& Rubiés 1999, p. 9). In and around the Christian holy land, this idea of material 
dominion was narrated in various forms of travel writing, moving back and forth across the Mediterranean in the fourth through sixth centuries. In this period, as Christianity ascended to power within the Roman Empire, the holy land became what Mary Louise Pratt has called a 'contact zone': 'the space of colonial encounters, the space in which peoples geographically and historically separated come into contact with each other and establish ongoing relations, usually involving conditions of coercion, radical inequality, and intractable conflict' (Pratt 1992, p. 6; see also 4). Through the travel writing emanating from this holy contact zone, the ideology of Christian Empire could be mapped in material terms; the Roman province could be venerated as the earthly manifestation of 'Jerusalem above' (Galatians 4.26; see Perrone 1999; Brox 1986).

The texts that scholars label 'pilgrimage narratives' did not arise ex nihilo in the literary landscape of the Mediterranean world (Hunt 1984, 1999; Frank 2000, pp. 37-59). Throughout the ancient Roman period, forms of travel writing, textual cartographies, served to negotiate local identity within an increasingly omnipresent Empire (Elsner \& Rubiés 1999, pp. 9-11; Elsner 2000). Travel writing produced forms of knowledge about other places and other times that situated the author (and audience) in a particular cultural location. For instance, the second-century Description of Greece written by the Greek antiquarian Pausanius has been interpreted as 'a guide to the formation of Greek religious identity as resistance to the realities of Roman rule' (Elsner 1995, p. 127; but see also Arafat 1996, para. 3). Likewise, the cartographic enterprise of Roman rulers has been viewed as an attempt to impose a unifying vision of empire on recalcitrant provinces (Sundwall 1996; Brodersen 1995; Elsner 2000, pp. 183-68). I do not want to argue that Christian travel writers deliberately worked from or appropriated or somehow 'Christianized' imperial modes of travel writing. Rather I wish to point out some of the ways in which travel itself could function in the ideological workings of the Roman Empire, and how Christian writing came to participate in this process (Elsner 2000; Frank 2000, pp. 37-49).

As veneration of the holy land took on a sacred and material importance to Christians after Constantine (Wilken 1992, pp. 82-125; Hunt 1999), interaction with the holy places and objects could be employed by Christians to tell themselves a new story of religious Empire. In this newly constructed imperial identity, the encounter with the Palestinian Jew (or the conspicuous erasure of such encounters) allowed the pious Christian traveler to inhabit a material world in which the Christian possessed power. ${ }^{2}$ These encounters encode materially enacted 'configurations of power' (Said 1978, p. 5) through which we can evaluate the various strategies employed to construct the imperial Christian subject in relation to a colonial Jewish 'other.' Importantly, not just the authors but the texts themselves are designed to 'travel,' to view a material reality and translate it back 'home,' where they can emerge as 'a primary ground for the production of new cultural forms' (MacCannell 1992, p. 1; see also Hunt 1972, pp. 362-73; Said 1994). Like Cosmas' universally accepted 'Roman coin,' the material representations of encounter and appropriation inscribed in these Christian travel writings of late antiquity circulated and created their own authoritative economy of Christian Empire. 'Travel writing needs to be perceived as a discourse in which imperatives of knowledge and power intersect in a constitutively reciprocal manner,' modern colonial theorists write (Dissanakyake \& Wickramagamge 1993, p. 7). In these particular forms of Christian travel writing - pilgrimage texts-we find these intersections of knowledge and power 'made flesh,' as it were, in the landscape of the holy land.

I have divided my overview of these Christian travel writings under four rubrics, according to various strategies for narrating the encounter between Christian subject and 
Jewish 'other': historicisation, by which the Jew or his remains is made to embody a Christian past; textualisation, by which the Jew and his vestiges are dissolved into the text of Christian Scriptures; aestheticisation, by which the Jew and his world are encoded into the sensory experience of the Christian; and ritualisation, by which Jewish religious practice (as represented by the Christian author) is made to reflect or reinforce the imperial religious conduct of the Christians themselves. Individual pilgrimage accounts will be used to exemplify these discrete textual strategies, although it is not my intention to impose univocity on these pilgrim narratives, or argue for a monolithic developmental model of the travel literature of the Christian Empire. In choosing to focus on narrative typologies rather than constructing some sort of linear or chronological explanatory model, ${ }^{3}$ I hope to demonstrate that these texts in fact produce multiple and even, at times, conflicting representations: the figural Jew of Christian travel literature is not a stereotyped or fixed icon of the Christian imagination, but rather a fluctuating and elusive figure (for ancient Christian as for modern scholar). In this fluctuation we shall trace the instability of early imperial Christian subjectivities, as well.

\section{II. 'You Would Say it Happened Today': Historicisation of the Jew}

We know very little about the pilgrim from Burdigala (modern Bordeaux, France) who made the overland journey to see the holy places in the year 333, at the height of the sole reign of Constantine the Great. Details such as name, status, age, and gender are lost to us, although we can make some assumptions: the traveler was a Christian from the western half of the Empire, who had the time, leisure, and (presumably) funds to make a long and possibly costly journey for reasons of piety and curiosity (see Casson 1974, pp. 176-86; Jones 1964, pp. 824-34, 841-4; Hunt 1982, pp. 57-8; Douglass 1996; Weingarten 1999). Scholars tend to give much attention to this document because it is 'the earliest surviving Christian account of travel to what came to be known as the Holy Land' (Douglass 1996, p. 313; see Cambell 1988, pp. 27-31). In form it is something of a hybrid: a long table of rest-stops and cities, with little in the way of actual detail, is interrupted in the middle by a denser account of the significant sites of the holy land (see Jones 1978, pp. 22-5; Elsner 2000, pp. 183-6; Levi 1967, pp. 25-33, 35-8). The difference between the narrative core of the document and the long, dry list of place-names and distances inscribes a certain tension between imperial geography and Christian history. E. D. Hunt has astutely pointed out the 'contrast' this formal organisation creates between 'Christian core' and 'secular' list of routes (1982, p. 58), and I would suggest that this contrast is integral to understanding the effect of this document in constructing a place for Christian material piety within the limits of Empire. Connections between the 'secular' and the Christian are perceptible in the text, just as the famous Roman roads are allowed to penetrate the more thickly textured space of the holy land (Casson 1974, pp. 184-5; Roll 1986, 1996). This connection is tenuous, however, and this ambivalence tells us something about the nature of this vision of Christianity and Empire (see Elsner 2000).

The tenuously bridged disjunction between Christian and imperial identities inscribed by the form of this document is also executed through the treatment of the pilgrim's 'figural Jews.' Some commentators have remarked that the pilgrim's account 'lacks any real interest in the native terrain, flora, fauna, or people' (Leyerle 1996, pp. 123-4; cf. 126). This seeming lack of 'real interest' is perhaps made more conspicuous due to our familiarity with such garrulous texts as those of Egeria or the Piacenza pilgrim, from a later period (see below). When taken on its own, however, the landscape of the 
Bordeaux pilgrim's holy land is, in fact, densely populated by the dead heroes of the Bible, mostly figures from the Old Testament. Indeed, they crowd his landscape as semivisible phantoms. The pilgrim's first narrative description of his travels comes when he reaches the city of Neapolis (Nablus), and he remarks:

There is Mount Gerizim. There (say the Samaritans) Abraham offered his sacrifice, and 300 steps rise up to the summit of the mountain. Then, at the foot of the mountain, is the place called Shechem. There is the monumental tomb (monumentum) where Joseph is buried, in the estate which his father Jacob gave to him. There was Dinah, Jacob's daughter, abducted by the sons of the Amorites (It. Bur., 587.2-8.2 [CCL 175, pp. 13-14]).

A host of biblical characters run hither and yon through the landscape, up and down the mountain, ordered through the mediating lens of Scripture and grounded in the material reality (monumentum) of the visible graves. Although the landscape may be described as 'lifeless,' it is not depopulated. The native population has been historicised, made to inhabit an ever-receding past, in such a way as to empty the land of live bodies. They have left remains, such as steps in a mountainside and monumental tombs. ${ }^{4}$ As Pratt has remarked, in writing about early modern travel literature, 'to revive indigenous history and culture as archaeology is to revive them as dead. The gesture simultaneously rescues them from European forgetfulness and reassigns them to a departed age' (1992, p. 134, emphasis original; cf. pp. 64-5). If the Jews are dead they cannot stand up and interact with the Christian pilgrim; they can only be viewed, displayed, and catalogued for future observers. The pilgrim thus creates a terrain populated by ghosts, past-tense inhabitants that are in some sense still visible, still significant to his own vision of the holy land, but now inert and inactive.

Indeed, their sluggish and immobile shadows at Neapolis obscure what must be contemporary Samaritans, who have provided the pilgrim or his guides with an alternative location for the biblical story of the binding of Isaac (Wilkinson 1981, pp. 154-5 nn. 8-11; Maraval 1985, pp. 288-9). Even these helpful Samaritans are gently nudged into the scriptural past in the next passage, where the pilgrim describes 'Shechar, where the Samaritan woman went down to the same place where Jacob dug a well, and she drew water from it and our lord Jesus Christ spoke with her' (It. Bur., 588.2-5 [CCL 175, p. 14]; cf. John 4). The 'real' inhabitants of this land are throughout the itinerary the long-dead Jews of the Old Testament, and their specters show that the Bordeaux pilgrim has traveled not only across Roman space but through Christian time. In this way, imperial travel has the power to access sacred history.

In the pilgrim's description of the Temple Mount in Jerusalem, the ghostly presence of the Jews accomplishes a complex looping of imperial space and sacred time. The passage is worth quoting in full:

There are in Jerusalem two great pools on the side of the Temple, that is, one to the right and the other to the left, which Solomon built. But inside the city there are the twin pools, having five porches, which are called Bethsaida. ${ }^{5}$ There those sick for many years used to be healed. Moreover these pools have water churned up, a sort of scarlet color. There is also a crypt, where Solomon used to torture demons. There is the corner of a very tall tower, where the Lord climbed up and said to the one who was tempting him, 'And the Lord said to him: You will not tempt the Lord your God, but him only will you serve' (Matt 4.5-11; Luke 4.1-8). There is also the great corner stone, about which it was said: 'That which the builders rejected, this same stone is the head of the corner' (Matt 21.42) and under the pinnacle of the tower are many chambers where Solomon had his palace. There also remains the chamber in which he 
sat and wrote Wisdom, and its roof is of a single stone. You also have there great underground cisterns and pools built with great toil, and in the building itself where was the Temple that Solomon built, before the altar in marble is the blood of Zacharias-you would say it had been shed today! Also all around are the traces of the hobnails of the soldiers who killed him, throughout the area, so that you might think they had been pressed in wax. There are there also two statues of Hadrian. There is also not far off from the statues a pierced stone, to which the Jews come every year, and they anoint it, and they cry out with a groan, and they tear their own garments, and in this way they withdraw. There is also there the house of Hezekiah, king of Judaea (It. Bur., 589.7-91.7 [CCL 175, pp. 14-16]).

This single site exists at several different chronological moments, and its ghostly inhabitants practically careen into each other in frenzied activity. Solomon the Temple builder alone is several places at once: building the Temple, torturing demons, writing placidly of wisdom. Every place we see Solomon, however, he is generally found next to Christian figures, such as Jesus on the Temple tower or Zechariah, who likely here signifies the father of John the Baptist, murdered in Christian legend by Herod the Great's soldiers (see Prot. Iac., 23.1-3 [Stycker 1965, pp. 400-1]). 'You would think' his blood was shed 'today,' so vivid and real are the ghosts that occupy this charged 'contact zone.' The past exists on display in the present, yet the pilgrim need not fear that these ghosts could act in any other manner than expected - they are, after all, still dead.

As the pilgrim proceeds through the Temple, he progresses also through time: we are next confronted with the incongruous statues of Hadrian, the emperor who expelled the last living Jews from Jerusalem following the Second Jewish War (ca. C.E. 132-5). The Emperor Aelius Hadrianus had remade the city into an imperial Roman colony bearing his name, Aelia Capitolina. Yet Hadrian's historical significance as dejudaiser of Jerusalem is undermined by the sudden presence 'not far from his statues' of our only glimpse of contemporary Jews, mourning at a pierced stone. Time, for the moment, seems to exist in an imperial present, marked by live Jews bereft by imperial force of their Temple.

Except, of course, that the Jews are no more 'alive' in this passage than the scriptural ghosts surrounding them; the pilgrim has been told about them (see Stemberger 2000, p. 93), and as soon as he evokes their invisible presence, mourning in typical Old Testament fashion (weeping and rending their garments) they are gone; the pilgrim has imagined their presence only to underscore their material absence from a Christian space: 'The image is at once a metaphoric substitution, an illusion of presence, and by that same token a metonym, a sign of its absence and loss' (Bhabha 1994a, p. 51). The Jews then 'depart' as quickly as they came from his imagination, and the mention of Hezekiah returns us to a scriptural ambiance: they only present Jews are now the dead biblical ones.

Scholars have long noted the Bordeaux traveler's interest in sites of the Old Testament, and have proffered various explanations (see Stemberger 2000, pp. 88-95); interestingly, many of them return to the question of contemporary Palestinian Jews. Either this pilgrim is supposed to have derived information directly from these (unnamed and, more importantly, uncited) Jews (Wilkinson 1990; Wilken 1992, pp. 110-11), or else he is himself alleged to be a Jew (or a converted Jew, or Jewish-Christian) (Donner 1979, p. 42). The assumption that attention to Jews in their Old Testament guise bespeaks Jewishness on the part of the pilgrim does not allow for the possibility that, in fact, a particular Christian identity is being inscribed through these representations. The representation of Jews as Old Testament figures, and their 
ambivalent placement within the imperial province of Palestine, allows the Bordeaux pilgrim to articulate some of the historicising power dynamics of imperial Christianity.

Yet at very few places does the Bordeaux pilgrim allow an explicitly imperial presence to exert itself within these holy places. Apart from 'Hadrian's statues,' the pilgrim mentions four churches recently built 'by command of Constantine' (It. Bur., 594.2-3, 595.5-6, 598.7, 599.5-6 [CCL 175, pp. 17, 18, 20]); these mentions are casually inserted between longer descriptions of nearby biblical events and catalogues of Old Testament tombs. The description of the Golgotha church follows a lengthy (for the Bordeaux pilgrim, at least) description of the crucifixion; the Eleona church is found between the tomb of 'Hezekiah, king of the Jews' and the sites of the Transfiguration and tomb of Lazarus; the Bethlehem church is wedged between a long list of local Old Testament tombs (Rachel, Ezekiel, Asaph, Job, Jesse, David, and Solomon, whose names are 'written in Hebrew letters'); and the Terebinth church is between the spring where Philip baptised the eunuch and the tombs of the Old Testament patriarchs and matriarchs. Imperial construction, like Roman roads, has encroached but little on the sacred space of the Christian holy land. Like Hadrian, the Bordeaux pilgrim cannot successfully manage to purge the land of its former inhabitants, the Jews; he is constantly surrounded by their ghosts, no more so than on the Temple Mount where they threaten to burst in and mourn like ancient Israelites.

In his study of early modern and modern travel writing, David Spurr has described the colonialist textual strategy of 'insubstantialization': 'the object of representation is seen as an immaterial counterpart to the dissolving consciousness of the subject, a dissolution which can be joyful . . or profoundly disorienting' (1993, p. 142). The 'disorientation' of seeing of the colonised object as if 'in a dream' can be both empowering and humbling, and, for the Bordeaux pilgrim, this ambivalent representation of the Jew as always historicised - as dead, yet somehow still there-underscores the ambivalent manifestation of imperial power in the Christian holy land. The itinerary format of document inscribes the material significance of Roman roads and stopping stations, of the imperial function of travel itself; yet that power exerts itself only fitfully in the limits of the holy places. Robert Markus has argued that Christian holy places themselves are the byproducts of Christian historical ambivalence, the attempt to 'bridge this generation gap' between 'the triumphant Church of the fourth and later centuries' and 'its persecuted predecessor' (1994, p. 269). The itinerary of the Bordeaux pilgrim neutralises the presence of the Jew through strategies of historicisation, and creates a Christian subjectivity with the power to view the Jewish presence on historical display. At the same time, however, this historicisation keeps the sites of Christian sanctity cut off from the full impact of imperial authority, allowing contemporary Jews the opportunity to slip in on occasion, groaning, mourning, and then vanishing (see now also Bowman 1999).

\section{III. 'Just the Man for the Place': Textualisation of the Jew}

If the Bordeaux pilgrim's representation of Jews serves to encode historical ambivalence between Christianity and Empire, between 'then' and 'now,' the more lively travel account of Egeria demonstrates how the Jewish past can be pressed into more immediate service for the Christian present through processes of textualisation. The pilgrim most likely named Egeria came to the holy places from Spain or Gaul in the early reign of Theodosius I, that emperor whose unified rule at the end of the fourth century ushered in a truly and officially 'Christian Empire' (Devos 1967; Sivan 1988; Hunt 1982, 
pp. 164-5; Hunt 2001). E. D. Hunt has called her narrative 'an authentic witness of "Theodosian" Christianity' (1982, p. 165) that is, a public form of piety that deliberately elaborated affiliations between imperial authority and Christian identity (Matthews 1975, p. 139). As a representative of this stream of western piety and eastern imperium, Egeria and her textualised representation of the Palestinian Jew create a purely Christian space for the exercise of piety and authority.

The seventh-century monk Valerius, in his letter praising 'the virtue and fragility' of this fearless woman, remarks that, driven by the 'flame of desire that burned in her holy heart,' Egeria 'accordingly read through all the books of the Old and New Testaments with all intrepidity, and sought out all the places to which holy miracles had been ascribed (conscripta), in whatever diverse parts of the world they might be found-in provinces, cities, mountains, and desert places' (Ep. Eg., 1 [SC 296, pp. 336-8]). Scholars have subsequently concurred that 'the main impetus' for Egeria's travel 'was the influence of the Bible' (Hunt 1982, p. 120; see also Mulzer 1996). Of all of our Christian travel writers, Egeria stands as the preeminent example of a 'textual attitude' towards the holy land (see Said 1978, pp. 83-4). Not only does 'sacred writing make this topography meaningful' for Egeria (Leyerle 1996, p. 127), it very simply makes this topography. Even sites completely devoid of monument or marker are made noteworthy by their scriptural resonance. This is demonstrated most fully in the first section of the travel diary, as Egeria travels through 'Moses-country'. Here empty vistas are imbued with significance solely due to their correlation to the 'books of Moses':

Then ... we were led to another place not far off, where priests and monks showed us that very spot where holy Aaron stood with the seventy elders, when holy Moses accepted the Law from the Lord for the children of Israel. So on that spot, although there is not even a structure, nevertheless there is a big, round rock, with a flat ridge on top, on which these very same saints stood! (It. Eg., 4.4 [SC 296, pp. 138-40])

A big, flat rock leaps out of an otherwise unremarkable landscape, animated by the scriptural text (and the accommodating local guides). At times it is clear that the text remains in some sense even more authentic than 'the very place.' Wearied by her descriptions of 'Moses-country,' Egeria tells her 'sisters' back home: 'All these things, one after another, it should suffice to write down, were there not simply too much to remember; but should Your Charity read the holy books of Moses, she will perceive everything that happened there most diligently' (It. Eg., 5.8 [SC 296, p. 146]; see Leyerle 1996, p. 127).

The most striking place where the text of Scripture creates landscape is in an empty plain near the village of Livias, where Egeria and her party pause to read a passage from Deuteronomy since 'this was the very place where Moses wrote the book of Deuteronomy' (It. Eg., 10.6 [SC 296, p. 168]. Here the site is devoid of both marker and specific scriptural referent, but claims significance as a textual monument to the text itself. Throughout these 'Moses' sections, especially, Egeria speaks of the 'custom' of her company: to arrive at a site, say a prayer, read an appropriate passage from the Bible, say another prayer, and move on (It. Eg., 10.7 [SC 296, p. 168]; see also 4.8, 6.3, 11.3, 12.3, 14.1 [SC 296, pp. 142, 154, 172, 174, 186]). Egeria's Moses, Aaron, and children of Israel inhabit texts, and they are invoked from and contained within the portable codex of Egeria's Bible, like amiable genies.

In a manner similar to the Bordeaux pilgrim, Egeria is constantly aware of the Old Testament dead: but where the Bordeaux pilgrim would see a monumentum, a material trace of Jewish natives, Egeria sees empty spaces and texts that inscribe the Jewish dead 
into her landscape. The closest she (and her readers) comes to viewing the material remains of a tomb is at Carneas, identified as the home of long-suffering Job. She relates the story of the discovery of Job's tomb. The discovery was made by the local clergy, following the ecstatic instructions of a hermit:

As they were digging in the place that was revealed to him [i.e., the hermit], they discovered a cave, which they followed through for about a hundred paces; suddenly, a stone appeared before the diggers. When they took a closer look at the stone, they discovered engraved on top of it the name JOB (It. Eg., 16.6 [SC 296, p. 194]).

Significantly, however, the tomb itself is no longer visible to Egeria: 'Nowadays, in Job's honor in this spot that church has been built which you can see, however it was built so that the stone and the body itself were not moved to another place but left here where they were found' (It. Eg., 16.6 [SC 296, p. 196]). Job's body is now entirely invisible, replaced by the text of Job left in Egeria's possession.

This Jewish absence is made fruitful for the production of Christian identity precisely by its absorption into biblical text: substituting textual Jews for Jewish remains allows Egeria to push her Christian appropriation of the holy places further than the Bordeaux pilgrim. The overlay of a Christian church on top of Job's body represents quite graphically Egeria's entire vision of the Christian holy places. On the level of the material text itself, we can contrast Egeria's notice with the Bordeaux pilgrim's method of historicising his dead Jews: in his account, he was careful to note that the graves of prophets and patriarchs, still visible, were inscribed with Hebrew characters of the names of the entombed (It. Bur., 598.7-9 [CCL 175, p. 20]). In Egeria's account, the name 'Job' is not only invisible, because it is covered by a church, but there is no attempt to 'historicize' Job's presence through the 'dead' language of Hebrew. Indeed, in Egeria's holy land, the 'native' language seems to be (Christian) Greek: she remarks several times on terms and names of sites 'as they are called here' in Greek, and provides a Latin translation (It. Eg., 3.4, 8.4, 13.4, 15.3, 24.1, 24.4, 24.5, 27.1, 46.2 [SC 296, pp. 132, 160, 184, 188, 238, 240, 258, 308]; see Dauphin 1998, pp. 133-55). The absorption of Hebrew text into Greek, while certainly not unique to Egeria, nonetheless reveals her assumptions about Christian text and Jewish past.

So, too, just as a church covers Job's tomb, we find that, at every site where she 'recognizes' the scriptural presence of Old Testament Jews, there are Christians installed in their place, Christians who fit the scriptural bill as well as, if not better than, the Old Testament's original actors (see Palmer 1994). Our extant manuscript of Egeria's travel diary begins with her traveling party scaling Mount Sinai: we have already seen how rich and textured 'Moses-country' was for Egeria. When her party reaches the top of Mount Sinai, she finds only the 'cave of holy Moses'; instead of some material remains of Moses himself, there is in his place 'a healthy old man, a monk from his boyhood and an "ascetic" as they call it here-in fact, just the man for the place (qualis dignus est esse in eo loco)' (It. Eg., 3.4 [SC 296, p. 132]). Likewise, at the spot where Melchizedek met Abraham, she meets a priest who is

now older and well versed in Scriptures, who presided over this spot after being a monk; about this priest numerous bishops, whose acquaintance we made later, bore favorable witness to his way of life, for concerning him they said that he was just the man to preside in this spot (dignus qui presit in hoc loco) (It. Eg., 14.2 [SC 296, p. 186]).

While in transit, she stops her guides to ask what 'special reason' there might be for a solitary monk's cell in the Jordan valley, and is told that this was where Elijah hid from 
Ahab (It. Eg., 16.1-4 [SC 296, p. 193]). While in some measure Egeria's vision of the holy land reproduces the effacing and historicising gestures of the Bordeaux pilgrim, the ghosts that haunted the pilgrim from Bordeaux have now graciously ceded their place to more fitting Christian tenants. It is noteworthy that the only active and mobile agents of Egeria's travel diary are, in fact, the monks and clergy who act as her holy-land tour guides. Jews, as contemporary residents of the land, have been completely textualised into the Christian past. ${ }^{6}$ The land is totally scriptural; Scripture is entirely Christian; the land becomes the site for Christians to become the texts they venerate (see Frank 2000, pp. 6-11, 29-33, 69-75, 168-73).

It is significant that this forceful appropriation of Jewish time and space occurred in the holy land of Theodosius I, the physical site where Christianity as 'new Israel' attained a literal and potent reality not seen in the days of Constantine. The flood of imperial interest and money into the holy land in this period surpasses Constantine's day, and Egeria's voyage is best viewed in the context of the concerted efforts of Theodosius and his family to portray themselves as both ultra-orthodox and ultraimperial (Matthews 1975, pp. 107-45; Hunt 1982, pp. 155-79, 221-48; Hunt 1997, pp. 52-7). Not even the rumored 'ghosts' of mourning Jews on the Temple Mount remain to haunt Egeria's rich landscape; the shadows of Moses and Elijah appear only as empty spaces next to the more apt Christian monks, through the process of appropriation and textualisation: 'It is always in relation to the place of the Other that colonial desire is articulated: the phantasmic space of possession that no one subject can singly or fixedly occupy, and therefore permits the dream of the inversion of roles' (Bhabha 1994a, p. 44). As Christians traveled through a reunified and securely orthodox Empire at the end of the fourth century (Spitzer 1949, p. 258), the holy land emerged as a nexus for this ideally homogeneous orthodox imperium. When Egeria reports the cacophony of languages into which the Jerusalem liturgy is translated at Easter, she testifies not so much to a diversity of Christian identities as to a unity of Christian imperialism (It. Eg., 47.3-4 [SC 296, p. 314]). All 'otherness' is absorbed and thus erased within a robust and totalising Christian identity. In Egeria's travel diary, it is the unifying force of Scripture, subsuming all otherness into wholly Christian text, that accomplishes this absorption and erasure: 'To posit the land as a text is to claim its readability, and thence to arrogate power over it' (Ryan 1994, p. 126; see also Spurr 1993, p. 92).

Despite this thorough textualisation, however, Egeria is unable to accomplish a complete Christianisation of this once-Jewish space. Her textual landscape fails, in the end, to accommodate successfully contemporary Jews into her Christian land. The Bordeaux pilgrim had been able to invoke the ghosts of Jewish mourners at the site of their empty Temple Mount, achieving in this way some measure of consonance between his scriptural cadavers and their Jewish descendants (cf. Pratt 1992, p. 52). When we read Egeria, we learn (presumably erroneously) that there simply are no Jews in the Theodosian holy land. Such an assertion displays the power of textualisation to rewrite the religious and cultural landscape, yet at the same time reveals the tension involved in articulating this space, as, at the same moment, entirely Christian and profoundly 'other' (see Bhabha 1994b, 1994c). If all Jews are supposed to have been replaced with more 'fitting' Christians, it is unclear what a good imperial Christian is supposed to do when confronted with an actual Jew, a situation that could certainly obtain in places such as Galilee, home to an increasing host of pilgrimage sites as well as high concentrations of Jewish populations in this period. ${ }^{7}$ Other strategies of landscape formation developed in early Christian travel writing to compensate, on some level, for this disjunction between domination and appropriation. 


\section{IV. 'This Province is like Paradise': Aestheticisation of the Jew}

I turn now to a later travel account, that of the so-called Piacenza pilgrim, who traveled from Italy to the holy land and Egypt some time between 560 and 570, in the wake of the eastern Emperor Justinian's reconquest of Italy and the brief reunification of Italian and Byzantine orthodoxy and imperium (on the date see Milani 1977, pp. 31-46). The travel writing of the Piacenza pilgrim is not centered on historical monuments, like the Bordeaux pilgrim's (although see It. Plac., 28, 30 [CCL 175, pp. 143-4]), nor on scriptural texts, like Egeria's (see Leyerle 1996, p. 134). While there is no particular reason to doubt that his motives for travel were as pious as those of either of these two pilgrims, the Piacenza pilgrim's judgment of the holy sites are more grounded in pleasure. His vision of the holy land incorporates the presence of cultural and religious others through strategies of aestheticisation and appropriation. By 'aestheticization' I mean the representation of the holy land as a primarily sensory (often visual) experience, one that gratifies an individual, whether that experience is of sites, persons, objects, sounds, and so forth (see Frank 2000, pp. 102-33). The reduction of material realities to aesthetic judgment inscribes at once distance and appropriation (consumption), as well as authenticity: the holy land offers up new, strange sensory data and the pilgrim receives and evaluates them ('good,' 'bad,' 'delicious'). The pilgrim is the consumer, and the holy land is consumed (see Spurr 1993, pp. 42-60).

As the Piacenza pilgrim moves through the self-consciously foreign land, his conclusions about cities and their populations revolve around their being 'good' or 'bad,' based not on some notion of biblical history or textual appropriateness, but on the pilgrim's own experiences. This different mode of imperial appropriation as aesthetic, sensual, and experiential allows this pilgrim to align less problematically his ideals of imperial domination and Christian identity. The ability to evaluate a site or object's aesthetic value is sometimes connected with its history or holiness, but often through no more than the suggestive juxtaposition of sentences. The first 'stop' out of Constantinople is 'the island of Cyprus, the city of Constantia, where Saint Epiphanius has his resting place. A beautiful city, delightful (deliciosa), garlanded with date palms' (It. Plac, 1 [CCL 175, p. 129]). Is the city deliciosa for its date palms, or for Epiphanius' tomb? The author does not specify, and it probably does not matter: both aspects of Constantia made it enjoyable in terms of the pilgrim's own experience. On the fringes of the holy land, cities generally receive such blanket judgments about their 'goodness': passing through the cities of Tyre and Ptolemais, for instance, on his approach to Galilee, the Piacenza pilgrim finds Tyre to be characterised by 'the worst sort of living, with so much decadence that it's impossible to speak of it'; while Ptolemais is, in contrast, 'an honest city, with good monasteries' (It. Plac., 2 [CCL 175, pp. 129-30]). Likewise, near the end of his journey, as his party passes through Egypt, he remarks that Alexandria is a 'shining city, with the shiftiest populace, but kind to pilgrims, at least' (It. Plac., 45 [CCL 175, p. 152]; cf. It. Plac., 33 [CCL 175, p. 145]). Here it is clear that such evaluations of cities and their populations in toto are based on the pilgrim's experience: the Alexandrians were kind to him, so he can forgive (to some degree) their overall 'shiftiness.'

Throughout this engaging piece of travel writing, it is often the experience of the senses that marks a site or an object for this pilgrim. Sight, smell, sound, touch, and taste permeate his account, and allow him to evaluate and appropriate his holy-land experience. He sees images of both Mary and Jesus; the former is among several relics of Mary housed at Golgotha (It. Plac., 20 [CCL 175, p. 139]); the latter is an imprint on 
linen on which Jesus had wiped his face: 'We venerated it, but could not gaze upon it on account of its splendor, since, as soon as you look upon it, it shifts before your eyes' (It. Plac., 44 [CCL 175, p. 152]; cf. It. Plac., 46 [CCL 175, p. 153]). The engagement of the visual sense makes the experience pleasurable, even when that experience is marked by disorientation. The pilgrim also delights in the tactile sensation of Jesus' footprints, noting that the shape of Jesus' foot was 'beautiful, well-measured, and delicate' (It. Plac., 23 [CCL 175, p. 141]). Smells also give dimension to the pilgrim experience, as demonstrated by the sanctifying 'incense and lights' of the liturgy at Mamre and the isolated healing shrine at Clysma, which 'has a certain sulfuric odor' (It. Plac., 30, 42 [CCL 175, pp. 134, 151]). The pilgrim also has the remarkable capability of layering aural experience on top of the tactile and visual: twice he inclines to touch stones marked by sanctity, and remarks on the uncanny sounds that reach his ears (It. Plac., 19, 22 [CCL 175, pp. 139-40]).

In addition, the tastes of the holy land permeate the Piacenza pilgrim's account at the level of sense perception. He drinks from the skull of the martyr Theodota; he partakes of the 'indescribably sweet water' near Rachel's tomb in Ramah; he learns how to sweeten water that has turned bitter during his trek through Egyptian desert; and he tastes green nuts straight off the boat from India "which men believe come from paradise, of such grace that as soon as you eat them, you are full' (It. Plac., 22, 28, 36, 41 [CCL 175, pp. 141, 143, 147, 151]). It is perhaps the portability of these tastes of the holy land that has made them so memorable and remarkable to the Piacenza pilgrim: he is constantly filling up jugs of water to take home, and his description of the delights of Jericho emphasises the transportability of holy land sweetness:

\begin{abstract}
The spring of water, which Elisha made sweet, waters all of Jericho. There they grow grapes for wine, which is given to those suffering from fever. There they grow dates that weigh a pound, some of which I took with me back home (in provincia), and I gave one to my lord, the patrician Paterius. There they grow a citron that weighs forty pounds and the branch of the fruit is two feet long and two fingers wide. There is a vine there, from which they fill whole baskets for sale on the Mount of Olives, and at Pentecost they make new wine out of it and sell it by the jarful (It. Plac., 14 [CCL 175, pp. 136-7).
\end{abstract}

This passage on the agricultural wonders of Jericho signals what is so significant for the Piacenza pilgrim about the sensory experience of the holy land: it is a materiality that is at once entirely 'natural' and native to the site (Jericho grapes sell by the bushel to pilgrims on Mount Olivet), and entirely exportable (Paterius can show his fellow Placentine nobles the one-pound date from the holy land). This material appropriation by the privileged traveler resonates with Cosmas' proud declaration of the universality of Roman coin, and we should not be surprised to see the Piacenza pilgrim exclaim that 'this province is like paradise' (It. Plac., 5 [CCL 175, p. 131]). It is a paradise from which the traveler may purchase and transport paradisiacal souvenirs of a sensuous and material variety.

In addition, the repeated presence of Jews sets the tone for this pilgrim's triumphant consumption of the Christian province. The journey starts at Constantinople, with a trip over land through Syria; this makes the cities of Galilee his first pilgrimage stops. He sees Mary's 'breadbasket' in Diocaesarea/Sepphoris, and the nuptial waterpots at Cana; next his party arrives in Nazareth, 'where there are many miracles' (It. Plac., 4-5 [CCL 175, p. 130]). The first stop in Nazareth is, in fact, the Jewish synagogue: 
In the synagogue there sits the book in which the Lord wrote his ABCs, and in this synagogue there is a bench on which he sat with other children. This table can be lifted and moved around by Christians, but the Jews are completely unable to move it, and it doesn't allow them to drag it outside. The house of Saint Mary is now a basilica, and her clothes are the cause of frequent miracles (It. Plac., [CCL 175, pp. 130-1]).

We might invent any number of scenarios to explain the Jews' 'inability' to lift the bench of their own synagogue. Some scholars have suggested that the Jews themselves operated this particular 'tourist' attraction for Christian visitors, charging them for the privilege of watching Jews (playacting) at struggling with their own bench (Taylor 1993, pp. 228-9; see also Graves 1954, pp. 44-5). Such Jewish participation is not implied in the text, however, and would certainly have detracted from this pilgrim's own perception of the tactile thrill of lugging a bench on which Jesus sat with the other (less memorable) children. In fact, the pilgrim seems to envision resistance on the part of the Jews: they are attempting, unsuccessfully, to drag the bench outside, to remove the spectacle from their synagogue. As far as the Piacenza pilgrim is concerned, the Christian visitors are appropriating Jewish space for their own delight and pious amusement, insisting the whole time that it remain Jewish space. Unlike Egeria's 'converted' spaces, where the once-Jewish had become completely Christian, the aesthetic experience of the pilgrim here would not be complete without the recognition and appropriation of the Jewish space as Jewish.

This delight in the Jewish is made even clearer when he incorporates the Jewish 'natives' into his pleasurable experience:

The Jewesses of this city are better looking than any other Jewesses in the whole country. They declare that this is Saint Mary's gift to them, for they also say that she was a relative of theirs. Though there is no love lost between Jews and Christians, these women are full of kindness (caritae). This province is like paradise, in wheat and in fruits like Egypt, a province of modest size, but that eclipses Egypt in terms of wine and oil and apples (It. Plac., 5 [CCL 175, p. 131]).

The Piacenza pilgrim's delight in Nazareth centers on its pleasurable Jewishness: from the synagogue and its miracles, to the astounding agronomic production, to the pretty Jewish girls whose very beauty is at once undeniably Jewish - they are, after all, the 'most beautiful Jewesses' in the country ${ }^{8}$ - but there, like the apples, wine, and synagogue, for the enjoyment of Christian men, part of the pleasant, colonialist 'fantasy of seduction' (Spurr 1993, pp. 173-7). It is Saint Mary's 'gift' to these men which preserves their beauty for Christian visitors, just as Mary's clothes in her old Jewish house cure disease.

This mode of aesthetic appropriation of space creates a new type of Christian landscape, one in which the 'otherness' of the Jews is brought into a fruitful proximity to the imperial, Christian self. Jews become the 'good' natives of this Christian province, now in contrast to the sinister Samaritans. Upon leaving the welcoming embrace of the beautiful Jewesses of Galilee, the pilgrim's party passed through Samaritan country: 'Going down through the countryside, there were cities and villages of the Samaritans; and wherever we passed, whether it was us or Jews, they burned up our footprints with straw, so great is their loathing of both' (It. Plac., 8 [CCL 175, p. 133]). Samaritans in earlier Christian discourses of heresy and historiography had acted as a sort of 'shadow-double' of the Jews; under Justinian, however, they became the specific object of imperial persecution, making them particularly apt receptacles for the 'terrifying stereotypes of savagery, cannibalism, lust and anarchy' (Bhabha 1994b, p. 72) in the 
Piacenza pilgrim's account (see Schur 1992, pp. 78, 82-92). What is striking here, however, is the positioning of Jews with Christians - 'us and them' on one side (sive nos sive Iudaei), the Samaritans on the other. As Leyerle has noted, 'the Piacenza pilgrim is attentive to native peoples' (1996, p. 135) in a manner that distinguishes his account from that of his pilgrim predecessors. But the Jews are not just another populus under the pilgrim's gaze. He may be intrigued by the outlandish appearance of the Ethiopians (It. Plac., 35 [CCL 175, p. 147]), and fascinated by the 'utterly marvelous' and idolatrous rites of the Saracens near Mount Sinai (It. Plac., 38 [CCL 175, pp. 148-9]). In the scope of this pilgrim's narrative, these are sights as wondrous and foreign as the 'lions, leopards, wild asses, and gazelles' (It. Plac., 39 [CCL 175, p. 149]). The exotic and foreign quality of the Palestinian Jews, however, is quite distinct. Their spectacle is made into Christian spectacle, and their presence adds a particular delight to the sites of Christian pilgrimage.

This is made especially clear in the pilgrim's description of the Oak of Mamre, where 'us and the Jews' are brought once more into close physical and conceptual proximity:

The basilica there was built with four porticos, with no roof over the central atrium. Through the middle runs a little screen (cancellus) and the Christians enter in one side, and the Jews on the other, carrying a lot of incense. For the deposition of Jacob and David is also celebrated in that place most devotedly, on the day after the Lord's birthday, such that from that whole land the Jews come together, an innumerable crowd, offering a lot of incense and lights and giving gifts to the ministers there (It. Plac., 30 [CCL 175, p. 144]).

Nothing but a cancellus divides Christian worship from Jewish-one day apart, footsteps away. The rites of the Jews pleasantly echo Christian celebration of the Nativity: Jewish culture becomes a particular facet of the pilgrim's own delight and piety, the familiar made strange, the exotic domesticated. The sights and sounds of the holy land belong to the pilgrim, and the sensory and aesthetic experience of Palestinian Jews demonstrate this completely. The accumulated sensory experiences of the Piacenza pilgrim make clear a sense of Christian privilege pervading his journey through the holy land, and the fact that the privileges of Empire and those of Christianity were indistinguishable. Power in Christians hands has become naturalised, to the extent that we might paraphrase Edward Said: 'The cumulative effect of decades of so sovereign an imperial handling has turned the holy land from alien into colonial space' (see 1978, p. 211). The aesthetic appropriation of the holy land by the Piacenza pilgrim, especially marked in his representation of the Jewish population of the Palestinian provinces, is one strategy by which Christian power and Empire achieve their fullest expression.

\section{V. 'According to our Custom': Ritualisation of the Jew}

In her discussion of early Christian maps of the holy land, Dorothea French remarked that 'just as with maps drawn on a flat surface, metaphorical mappings reflect the biases and idealised view of the sacred held by each mapper' (French 1991, p. 797). In this essay I have examined only some of the ways in which Christian travelers to the holy land 'mapped' their own imperial desires and fears, using the local Jew as the metaphorical legend to their maps. One impression I wish to avoid is that this was a process that solidified and became more secure over time: that, somehow, the Piacenza pilgrim managed this imperial mapping 'better' than the Bordeaux pilgrim or Egeria precisely because he and his pilgrim companions had more practice, or had acquired more colonialist expertise. These three strategies-historicisation, textualisation, and aestheticisation — were neither entirely discrete nor qualitatively more or less successful. 
Each text is embedded in a historical particularity, and constructs its Christian topography accordingly. To demonstrate both the overlap and instability of these topographies and their different strategies for metaphorical mapping, I would like to supplement the above analyses with a fourth strategy for mapping this imperial Christian space, a strategy that is shared by all three of the authors I have examined.

The Bordeaux pilgrim, Egeria, and the Piacenza pilgrim all engage in processes of ritualisation in their representations of the holy land, and their articulations of Christian identity therein. These textually represented rituals inscribe hierarchies into their holy land, hierarchies that reinforce the imperial presence of Christian cultural domination in the holy places. Jonathan Z. Smith has already drawn attention to the significance of ritual and ritualisation in the Constantinian construction of the Christian holy land. It was, according to Smith, a cultural production that emphasised at once antiquity and novelty, materiality and ideology:

Constantine created, for the first time, a Christian 'Holy Land,' laid palimpsest-like over the old, and interacting with it in complex ways, having for its central foci a series of imperial dynastic churches. ... [W] hat Constantine accomplished with power and wealth was advanced by rhetors like Eusebius who built a 'Holy Land' with words (1992, p. 79).

One crucial intersection of 'power' and 'words' came in the enunciation of Christian ritual: 'In the Christian Jerusalem of the fourth century, gesture and story could be brought together in a unique fashion. . . . In Jerusalem, story, ritual, and place could be one' (Smith 1992, p. 86). Here, Smith posits, doing ('gesture') and telling ('story') were brought into conjunction in order to subsume the time and place of biblical antiquity into a new sort of Christian identity. One vital aspect of this ritualisation of the holy places is the production of hierarchies: 'Ritual is, above all, an assertion of difference. . . Ritual is systematic hierarchy par excellence' (Smith 1992, pp. 109-10; see also Bell 1992, pp. 169-223). It is no surprise, then, that our pilgrim authors use the representation of ritual to construct appropriate hierarchies between the 'others' of their travel writing and their own Christian selves.

The more laconic and historicised itinerary of the Bordeaux pilgrim has infrequent mentions of contemporary activity, but two instances listed in close proximity portray the hierarchical relations of Christian and Jew, and the problematic intervention of imperial domination. Near the end of the description of the Temple Mount, cited above, comes the reference to the 'mourning Jews' who come every year to anoint the pierced stone 'not far off' from the two statues of Hadrian: 'the Jews come every year, and they anoint it, and they cry out with a groan, and they tear their own garments, and in this way they withdraw' (It. Bur., 591.5-6 [CCL 175, p. 16]). Groaning and tearing of garments are typical Old Testament indications of ritualised mourning (2 Samuel 3; Ward 1972; Feldman 1972), appropriate gestures for Jews who are made to shrink back into their own biblical history. Leaving the Temple Mount, and passing by Pontius Pilate's praetorium, the Bordeaux pilgrim looks at Golgotha, 'where, by order of Emperor Constantine a basilica was built, that is a church (dominicum), having on its side reservoirs of remarkable beauty, from which water is drawn, and a bath behind it, where the infantes are washed' (It. Bur., 594.3-4 [CCL 175, p. 17]). The baptistery of the Church of the Holy Sepulcher seems to be indicated here (Wharton 1992, pp. 313-25), although there is a notable lack of precision in the ritual terminology: balneum instead of fons, lavantur instead of baptizantur; even basilica needs to be glossed. 
The key indication seems to be infantes, which would refer to 'newly born' Christian baptizands, and not literal children (Wharton 1992, p. $315 \mathrm{nn} .13-14$ ).

So the juxtaposition here lies between the ancient mourning of ghostly Jews and the joyous washing of newly created Christians. The discourse of ritualisation seems to reinforce the Bordeaux pilgrim's historicising tendencies. Yet we should also note the increased significance of the imperial presence here: while the significance of Empire can be characterised as, at best, ambiguous in the totality of the itinerary, in these isolated passages of ritual representation imperial might takes on heightened significance as the instigator of ritual. Hadrian (through his two statues) is indicated as the responsible party for the mourning of the Jews, while Constantine has provided the physical structure for Christian initiation, and even made the reservoirs 'remarkably beautiful.' Not only ritual itself, but the juxtaposition of rituals through imperial agency impresses upon the reader Christian triumph and Jewish despair.

Egeria's travel diary is notoriously ritual heavy: her detailed description of the Easter celebration in Jerusalem, appended to the travel portions of the diary, has been mined by liturgiologists and historians as confirmation or extrapolation of the ritual texts of Cyril, bishop of Jerusalem during this period (Johnson 1988). The totalising and comprehensive sweep of Empire seems to be represented by these Jerusalem gatherings: on the anniversary of Constantine the Great's dedication of the Golgotha church (a holiday called the Encaenia, or 'Rededication'), for instance, not only monks, but 'layfolk (seculares), as many men as women, faithful of soul, on account of the holy day from every province gather together at the same time in Jerusalem' (It. Eg., 49.2 [SC 296, p. 318). The Encaenia 'ranks equal with Easter or Epiphany,' according to Egeria (It. Eg., 49.3 [SC 296, p. 318]); of course, it is a feast that is uniquely suited to celebration in post-Constantinian Jerusalem, a ritual celebrating the very institution of holy-land ritual. The dedication feast celebrates Empire and Christian ritual at the same moment, a sort of 'national holiday' for the Christian holy land.

The Jerusalem rituals are described with painstaking detail, but the more pervasive form of ritualisation in Egeria's account centers on the alignment of Scripture and site, or, to use Leo Spitzer's phrase, the affinity between locus (passage) and locus (locality) (1949, p. 239). In her description of Mount Sinai, Egeria sets the tone for the rest of her journey: 'Therefore on this very spot (ipso loco) we read the whole passage from the book of Moses, and we made the offering in the appropriate order' (It. Eg., 3.6 [SC 296, pp. 132-4]; see Devos 1973). This juxtaposition of site, text, and eucharist seems to be Egeria's idea:

There [i.e., at Elijah's cave] we made the offering and a most earnest prayer, and a reading was done from the appropriate passage (ipse locus) from the book of Kings: indeed, for our group this was what I desired most of all, that, wherever we went, the appropriate passage (ipse locus) would always be read from its book (It. Eg., 4.3 [SC 296, p. 138]; see Spitzer 1949, pp. 228-31).

This performance of reading and prayer (sometimes with communion) becomes 'customary' for Egeria's travel party, serving to transform the holy places into Christian sites through simultaneous textualisation and ritualisation (see It. Eg., 14.1, 15.4, 19.2, 20.3, 21.1, 23.5 [SC 296, pp. 188, 202, 214, 222, 230]). This interaction of text and ritual in Egeria's account even serves to provide the appropriate scriptural foundation for what seems a thoroughly imperial celebration: the feast of Encaenia, mentioned above (the anniversary of the Golgotha church dedication) is transformed, through ritual textualisation, into a feast with its own 'appropriate reading': 'It is found in the holy 
Scriptures that this very day was the Encaenia, when also holy Solomon had the house of God dedicated, which he had built, and he stood before the altar of God and he prayed, just as it is written in the books of Chronicles' (It. Eg., 48.2 [SC 296, p. 316]; see 2 Chronicles 6-7). Here Egeria's texts reinstitute the erasure of the Jewish past by overlaying Solomon and his Temple with Constantine and his church: the emperor now becomes 'just the man for the place,' and Solomon gracefully and prayerfully bows out before him. ${ }^{9}$

Just as the Bordeaux pilgrim and Egeria reinforce and nuance their textual strategies through the hierarchical processes of ritualisation, so too the Piacenza employs ritual to bolster his thoroughly material alignment of imperial and Christian interests. I have already mentioned above how Jews in his account are distinguished from other 'peoples' encountered on the road by their special proximity to Christians. After visiting Elijah's cave and participating in the eucharist as well as a customary depilatory rite with other pilgrims and monks (It. Plac., 37 [CCL 175, p. 148]), the Piacenza pilgrim immediately launches into a description of a Saracen rite that takes place on Mount Sinai:

And on this mountain, on part of the hill, the Saracens have set up their own marble idol, as white as snow. Their priest remains there as well, dressed in a dalmatic and a linen cloak. When the time of their festival arrives, at the new moon, before the moon has risen, on the day of their feast that marble begins to change color: as soon as the moon has appeared, when they begin to worship (adorare), the marble has become as black as pitch. When the time of the festival has been completed, it is returned to its original color, at which we were entirely amazed (It. Plac., 38 [CCL 175, pp. 148-9]).

The Saracen ceremony is exotic, miraculous, idolatrous (yet there is no overt condemnation of such idolatry), but it is mostly foreign: suum and ipsorum ('their own') appear four times in this brief passage, and the final 'amazement' of the pilgrims themselves encodes the entire ceremony as spectacle, amusement, completely 'other' entertainment. The ceremonies of the Jews, by contrast, are extremely close: recall that 'little screen' (cancellus) dividing Jewish from Christian worshippers at the Oak of Mamre, ritualised into the 'single day' that separates the Jewish celebration of the deposition of Jacob and David from the Christian celebration of Christmas. Aesthetic appropriation is stratified, ritualised description separates the proximate from the distant 'other,' marks out the proper domain of Christian domination and appropriation from that which is entirely exotic and strange.

All three of these documents make use of ritual to emphasise and reiterate hierarchy and difference. In conclusion, I want to note also that, as 'traveling texts' (see Said 1983), records of travel writing that were themselves made to travel across the Mediterranean, these documents are themselves ritually effective: as Edward Said has remarked, 'Texts are a system of forces institutionalized at some expense by the reigning culture, not an ideal cosmos of ideally equal poems' (Said 1979, p. 189; see also Stemberger 2000, p. 87; Frank 2000, p. 4; Elsner 2000, p. 181). They enact, for readers, these instances of appropriation and differentiation, they become themselves sites of difference and loci of power: 'The structures of writing and those of political power can never wholly be distinguished from one another' (Spurr 1993, p. 93). The potential for discursive power that traveling texts and texts of travel might bear in the ancient world should not be underestimated, and I have attempted, in this essay, to suggest ways in which these particular textual 'maps' of the holy land encoded configurations of power 
and religious domination: as Robert Wilken has astutely remarked, 'Space is never ideologically neutral' (Wilken 1992, p. 114). The travel writings of the early Christian empire, in their particular figurations and appropriations of the Palestinian Jew, serve at a fundamental level to naturalise and authenticate the newly founded exercise Christian power.

\section{Acknowledgements}

An abbreviated version of this paper was presented at the 1998 Society of Biblical Literature/ American Academy of Religion Annual Meeting in Orlando, Florida. I would like to thank Dale B. Martin who organised the panel on postcolonial criticism in early Judaism and Christianity, the other members of the panel (Cynthia Baker, Christopher Frilingos, and Hayim Lapin), and particularly our respondent, Jonathan Z. Smith. For additional suggestions and comments, I would also like to thank Susan Weingarten.

\section{Notes}

1 For abbreviations of primary texts and the critical editions from which they are cited, see the list of references at the end of the article.

2 On the demographic presence of Jews in Palestine during this period, see Avi-Yonah 1976, p. 17; Ma'oz 1988; Groh 1988; Aviam 1999; and Jacobs 1999. In speaking of 'figural Jews' in Christian writings, it is not my intention to erase or otherwise obscure the existence of 'real Jews'; I do also believe, however, that these 'real Jews' were 'really affected' by the imperial discourses of Christians.

3 I would like to thank Jonathan Z. Smith for suggesting the term 'typologies' to describe these interrelated forms of discourse.

4 Monumentum is the Bordeaux pilgrim's preferred term for these biblical graves, suggesting at once the historicity and public visibility of the tombs: It. Bur., 595.2-4 (Isaiah and Hezekiah), 596.5 (Lazarus), 598.4-5 (Rachel), 598.7 (Ezekiel, Asaph, Job, Jesse, David, and Solomon) (CCL 175, pp. 17-18, 19-20). Twice the pilgrim also uses cripta (596.2: Lazarus; 598.8: Ezekiel et al. [CCL 175, pp. 18, 20]) and once uses only the word memoria (599.8: Abraham, Isaac, Jacob, Sarah, Rachel, and Leah [CCL 175, p. 20]).

5 The reference from John 5.2 to the pools of Beth-Zatha was often transcribed in early Latin manuscripts as 'Bethsaida' (as here) or 'Bethesda' (as the King James Version called it). Confusion arose early in the manuscript transmission between the pools of Beth-Zatha and the city of Bethsaida in Galilee, home town of Philip, Andrew, and Peter (see John 1.44). I thank one of the readers for Religion for suggesting I explain this discrepancy.

6 Although I am here restricting myself to visions of the holy land, sensu stricto, I should note an additional telling instance of textualisation, effacement, and appropriation that takes place during Egeria's Mesopotamian excursion. In the city of Carrae she is promised a visit to 'Abraham's house.' When she arrives, she sees instead a 'church where Abraham's house used to be,' and where there is now a martyrium to a saint named Helpidius, at whose feast 'they also commemorate holy Abraham' (It. Eg., 20.5 [SC 296, pp. 214-16]).

7 Our only indication that Egeria visited Galilee remains in excerpts of her travel diary preserved by the twelfth-century librarian of Monte Cassino Peter the Deacon (summarised and combined with passages from Bede): Liber de locis sanctis V 4 (CCL 175, p. 99), in which Jesus curses (maledixit) Jews building a synagogue such that 'since then, whenever the Jews wished (voluerunt) to build it, whatever they had made by day was destroyed by night'; cf. also Liber de locis sanctis V 2 (CCL 175, p. 98) on the (apparently unused) synagogue of Capernaum. On these passages, see Leyerle 1999.

8 Simon Mimouni's theory that the 'Jewesses' (Hebraeae) of this passage are, in fact, 'JewishChristians' of some sort (see Mimouni 1992, pp. 171-82) I think misses the point of this anecdote.

9 According to Pierre Maraval, Constantine chose the date of the Encaenia to dedicate this church, not based on the biblical date, but because it was the date of the dedication of the Capitoline Temple in Rome: SC 296, pp. 316-17 n. 1. 


\section{Bibliography}

Antonini Placentini Itinerarium [It. Plac. [1965]

Arafat, K. W. 1996

Avi-Yonah,

Michael 1976

Aviram, Mordechai 1999

Text in Itineraria et alia geographica, 129-53. Ed. by P Geyer. Corpus Christianorum, Series Latina [CCL] 175. Turnhout: Brepols.

Pausanias' Greece: Ancient Artists and Roman Rulers. Cambridge: Cambridge University Press.

The Jews of Palestine. New York: Shocken.

'Christian Galilee in the Byzantine Period', in Galilee Through the Centuries: Confluence of Cultures, 281-300. Ed. by Eric M. Meyers. Duke Judaic Studies 1. Eisenbrauns: Winona Lake.

Bell, Catherine 1992

Bhabha, Homi K. 1994a $1994 b$ $1994 c$

Bowman, Glenn 1999

Brodersen, Kai 1995

Brox, N. 1986

Cambell, Mary 1988

Cansdale, Lena 1995

Casson, Lionel 1974

Cosmas

Indicopleustēs [1968-73]

Dauphin, Claudine 1998

Devos, Paul 1967 1973

Ritual Theory, Ritual Practice. Oxford: Oxford University Press.

'Interrogating Identity: Frantz Fanon and the Postcolonial Prerogative', in The Location of Culture, 40-65. London: Routledge.

'The Other Question: Stereotype, Discrimination and the Discourse of Colonialism', in The Location of Culture, 66-84. London: Routledge.

'Sly Civility', in The Location of Culture, 93-101. London: Routledge.

" "Mapping History's Redemption": Eschatology and Topography in the Itinerarium Burdigalense, in Jerusalem: Its Sanctity and Centrality to Judaism, Christianity, and Islam, 163-87. Ed. by Lee I. Levine. New York: Continuum.

Terra Cognita: Studien zur römischen Raumerfassung. Spudasmata 59. Hildesheim: G. Olms.

'Das "irdische Jerusalem" in der altchristlichen Theologie', Kairos n.s. 28:152-73.

The Witness and the Other World: Exotic European Travel Writing, 400-1600. Ithaca: Cornell University Press.

'Cosmas Indicopleustes: Merchant and Traveller', in Akten des XII. internationalen Kongresses für Christliche Archäologie (Bonn 22.-28. september 1991), 609-16. Ed. by Josef Engemann. Jahrbuch für Antike und Christentum 20.1/Studi di antichità cristiana 52. Vatican City: Pontifical Institute of Christian Archaeology; Münster: Aschendorffsche Verlag.

Travel in the Ancient World. London: George Allen \& Unwin Ltd.

Topographia christiana [Top. chr.]. Text and French translation in Topographie chrétienne, 3 vols. Ed. by Wanda Walska-Conus. Source Chrétiennes [SC] 141, 159, 197. Paris: Editions du Cerf.

La Palestine byzantine: Peuplement et populations. 3 vols. Biblical Archaeology Review International Series 726. Oxford: Archaeopress.

'La date du voyage d'Égérie', Analecta Bollandiana 85:165-94.

“"Lecto ergo ipso loco": A propos d'un passage d'Égérie (Itinerarium III,6)', in Zetesis: Album amicorum, 646-54. Antwerp: Nederlandsche Boekhandel.

Dissanakyake, Self and Colonial Desire: Travel Writings of V.S. Naipaul. Studies of World Wimal and Carmen

Wickramagamge 1993

Donner, Herbert 1979

Douglass, Laurie 1996

Elsner, Jaś 1995

2000

Pilgerfahrt ins Heilige Land: Die ältesten Berichte christlicher Palästinapilger (4.-7. Jahrhundert). Stuttgart: Verlag Katholisches Bibelwerk.

'A New Look at the Itinerarium Burdigalense', Journal of Early Christian Studies 4:313-33.

Art and the Roman Viewer. Cambridge: Cambridge University Press.

'The Itinerarium Burdigalense: Politics and Salvation in the Geography of Constantine's Empire', Journal of Roman Studies 90:181-95. 
Elser, Jaś and Joan-Pau Rubiés

(Eds.) 1999

Feldman, Emanuel 1972

Frank, Georgia 2000

French, Dorothea R. 1991

Graves, Robert 1954

Groh, Dennis 1988

Hunt, E. D. 1972

1982

1984

1997

1999

2001

Itinerarium

Burdigalense [It.

Bur.] [1965]

Itinerarium Egeriae

[It. Eg.]

[1982]

Jacobs, Andrew S. 1999

Johnson, Maxwell E. 1988

Jones, A. H. M. 1964

Jones, Tom B. 1978

Levi, Annalina 1967

Leyerle, Blake 1996 1999

MacCannell, Dean 1992

Ma'oz, Zvi 1988
Voyages and Visions: Towards a Cultural History of Travel. London: Reaktion Books.

'The Rabbinic Lament', Jewish Quarterly Review 63:51-75.

The Memory of the Eyes: Pilgrims to Living Saints in Christian Late Antiquity. Transformation of the Classical Heritage 30. Berkeley: University of California Press.

'Mapping Sacred Centers: Pilgrimage and the Creation of Christian Topographies in Roman Palestine', in Akten des XII. internationalen Kongresses für Christliche Archäologie (Bonn 22.-28. september 1991), 792-7. Ed. by Josef Engemann. Jahrbuch für Antike und Christentum 20.1/Studi di antichità cristiana 52. Vatican City: Pontifical Institute of Christian Archaeology; Münster: Aschendorffsche Verlag.

Count Belisarius. London: Penguin.

'Jews and Christians in Late Roman Palestine: Towards a New Chronology', Biblical Archaeologist 51:80-96.

'Saint Silvia of Aquitaine: The Role of a Theodosian Pilgrim in the Society of East and West', Journal of Theological Studies n.s. 23:351-73.

Holy Land Pilgrimage in the Later Roman Empire, AD 312-460. Oxford: Clarendon Press.

'Travel, Tourism and Piety in the Roman Empire: A Context for the Beginnings of Christian Pilgrims', Echos du Monde Classique 28:391-417.

'Theodosius I and the Holy Land', Studia Patristica 29:52-57.

'Were There Christian Pilgrims before Constantine?', in Pilgrimage Explored, 25-40, in J. Stopford. Suffolk: York Medieval Press.

'The Date of the Itinerarium Egeriae', Studia Patristica 38:410-16.

Text in Itineraria et alia geographica, 1-26. Ed. by P. Geyer and O. Cuntz.

Corpus Christianorum, Series Latina [CCL] 175. Turnhout: Brepols.

Text and French translation in Égérie, Journal de voyage, 121-319. Ed. by Pierre Maraval. Sources Chrétiennes [SC] 296. Paris: Editions du Cerf.

'Visible Ghosts and Invisible Demons: The Place of Jews in Early Christian Terra Sancta', in Galilee Through the Centuries: Confluence of Cultures, 359-76. Ed. by Eric M. Meyers. Duke Judaic Studies 1. Eisenbrauns: Winona Lake.

'Reconciling Cyril and Egeria on the Catechetical Process in FourthCentury Jerusalem', in Essays in Eastern Initiation, 18-30. Ed. by Paul Bradshaw. Nottingham: Grove Books.

The Later Roman Empire, 284-602: A Social, Economic, and Administrative Survey. Norman: University of Oklahoma Press.

In the Twilight of Antiquity: The R.S. Hoyt Memorial Lectures (1973). Minneapolis: University of Minnesota Press.

Itineraria picta: Contributo allo studio della Tabula Peutingeriana. Rome: Brettschneider.

'Landscape as Cartography in Early Christian Pilgrimage Narrative', Journal of the American Academy of Religion 64:119-43.

'Pilgrims to the Land: Early Christian Perceptions of the Galilee', in Galilee Through the Centuries: Confluence of Cultures, 348-53. Ed. by Eric M. Meyers. Duke Judaic Studies 1. Eisenbrauns: Winona Lake.

Empty Meeting Grounds: The Tourist Papers. London: Routledge.

'Comments on Jewish and Christian Communities in Byzantine Galilee', Palestine Exploration Quarterly 117:59-68. 
Maraval, Pierre 1985

Markus, Robert 1994

Matthews, John 1975

Milani, Celestina 1977

Mimouni, Simon 1992

Mulzer, Martin 1996

Palmer, Andrew 1994

Perrone, Lorenzo 1999

Peter the Deacon [1965]

Pratt, Mary Louise 1992

Protevangelium Iacobi

[Prot. Iac.]

Roll, Israel

1986

1996

Ryan, Simon 1994

Said, Edward 1978

1979

1983

1994

Schur, Nathan 1992

Sivan, Hagith 1988

Smith, Jonathan Z. 1992

Spitzer, Leo 1949

Spurr, David 1993
Lieux saints et pèlerinages d'Orient: Histoire et géographie des origines à la conquête arabe. Paris: Éditions du Cerf.

'How on Earth Could Places Become Holy? Origins of the Christian Idea of Holy Places', Journal of Early Christian Studies 2:257-71.

Western Aristocracies and Imperial Court, AD 364-425. Oxford: Clarendon.

Itinerarium Antonini Placentini: Un viaggio in Terra Santa del 560-570 d.C. Scienze filologiche e letteratura 7. Milan: Università Cattolica del Sacro Cuore.

'Pour une définition nouvelle du judéo-christianisme ancien', New Testament Studies 38:171-82.

'Mit der Bible in der Hand? Egeria und ihr "Codex", Zeitschrift der deutsches Palästina-Vereins 112:156-64.

'Egeria the Voyager, or the Technology of Remote Sensing in Late Antiquity', in Travel Fact and Travel Fiction: Studies on Fiction, Literary Tradition, Scholarly Discovery and Observation in Travel Writing, 39-53. Ed. by Zweder von Martels. Brill Studies in Intellectual History 55. Leiden: Brill.

'The Mystery of Judaea' (Jerome, ep. 46): The Holy City of Jerusalem Between History and Symbol in Early Christian Thought', in Jerusalem: Its Sanctity and Centrality to Judaism, Christianity, and Islam, 221-39. Ed. by Lee I. Levine. New York: Continuum.

Liber de locis sanctis. Text in Itineraria et alia geographica, 91-103. Ed. by R. Weber. Corpus Christianorum, Series Latina [CCL] 175. Turnhout: Brepols.

Imperial Eyes: Travel Writing and Transculturation. London: Routledge.

See Stycker 1965.

'The Roman Road System in Judaea', Jerusalem Cathedra 3:136-61.

'Roads and Transportation in the Holy Land in the Early Christian and Byzantine Times', in Akten des XII. internationalen Kongresses für Christliche Archäologie (Bonn 22.-28. september 1991), 1166-70. Ed. by Josef Engemann. Jahrbuch für Antike und Christentum 20.1/Studi di antichità cristiana 52. Vatican City: Pontifical Institute of Christian Archaeology; Münster: Aschendorffsche Verlag.

'Inscribing the Emptiness: Cartography, Exploration and the Construction of Australia', in De-Scribing Empire: Post-Colonialism and Textuality, 115-30. Ed. by Chris Tiffin and Alan Lawson. London: Routledge.

Orientalism. New York: Pantheon Books.

'The Text, the World, the Critic', in Textual Strategies: Perspectives in Post-Structuralist Criticism, 161-89. Ed. by Josu V. Harari. Ithaca: Cornell University Press.

'Traveling Theory', in The World, the Text, and the Critic. Cambridge: Harvard University Press.

Culture and Imperialism. New York: Alfred Knopf.

History of the Samaritans. Beiträge zur Erforschung des Alten Testaments und des Antiken Judentums 18. Frankfurt am Main: Peter Land.

'Who Was Egeria? Piety and Pilgrimage in the Age of Gratian', Harvard Theological Review 81:59-72.

To Take Place: Toward Theory in Ritual. Chicago Studies in the History of Judaism. Chicago: University of Chicago Press.

'The Epic Style of the Pilgrim Aetheria', Comparative Literature 1:225-58.

The Rhetoric of Empire: Colonial Discourse in Journalism, Travel Writing, and Imperial Administration. Post-Contemporary Interventions. Durham: Duke University Press. 
Stemberger, Günter Jews and Christians in the Holy Land: Palestine in the Fourth Century. Tr. Ruth 2000

Stycker, Émile

1965
Sundwall, Gavin A.
1996 Tuschling. Edinburgh: T \& T Clark.

'Une ancienne version latine du protévangile de Jacques', Analecta Bollandiana 83:351-410. 1996

Taylor, Joan E. 1993

Valerius [1982]

'Ammianus Geographicus', American Journal of Philology 117:619-43.

Christians and the Holy Places: The Myth of Jewish Christian Origins. Oxford: Clarendon.

Epistula de beatissimae Egeriae [Ep. Eg.]. Text and French translation in Éérie, Journal de voyage, 336-49. Ed. by Manuel C. Díaz y Díaz. Sources Chrétiennes [SC] 296. Paris: Editions du Cerf.

Ward, Eileen F. 1972

'Mourning Customs in 1, 2 Samuel', Journal of Jewish Studies 23:1-27, 146-66.

Weingarten, Susan 1999

'Was the Pilgrim from Bordeaux a Woman? A Reply to Laurie Douglass', Journal of Early Christian Studies 7:291-97.

Wharton, Annabel

Jane

'The Baptistery of the Holy Sepulcher in Jerusalem and the Politics of Sacred Landscape', Dumbarton Oak Papers 46:313-25. 1992

Wilken, Robert 1992

Wilkinson, John 1976

1981

1990

The Land Called Holy: Palestine in Christian History and Thought. New Haven: Yale University Press.

'Christian Pilgrims in Jerusalem During the Byzantine Period', Palestine Exploration Quarterly 108:75-101.

Egeria's Travels to the Holy Land. Warminster: Aris \& Phillips.

'Jewish Holy Places and the Origins of Christian Pilgrimage', in The Blessings of Pilgrimage, 41-53. Ed. by Robert Ousterhout. Illinois Byzantine Studies 1. Urbana: University of Illinois Press.

Wolska, Wanda La Topographie chrétienne de Cosmas Indicopleustès: Théologie et science au VIe 1962 siècle. Etudes Byzantines 3. Paris: Presses Universitaires.

ANDREW S. JACOBS is an Assistant Professor of Religious Studies at the University of California, Riverside, where he teaches courses in biblical studies and ancient Judaism and Christianity. He received his Ph.D. from the Graduate Program in Religion at Duke University in 2001.

Department of Religious Studies, University of California, Riverside, Riverside, CA 92521, U.S.A., andrew.jacobs@ucr.edu 